Annals of Warsaw University of Life Sciences - SGGW

Land Reclamation No 46 (3), 2014: 181-196

(Ann. Warsaw Univ. of Life Sci. - SGGW, Land Reclam. 46 (3), 2014)

\title{
What has changed in France in coastal flood risk management after Xynthia storm
}

\author{
JEAN CUNGE $^{1}$, MARC ERLICH $^{2}$ \\ ${ }^{1}$ Retired, Société Hydrotechnique de France \\ ${ }^{2}$ ARTELIA Eau et Environnement, Water Resources Modelling Branch
}

\begin{abstract}
What has changed in France in coastal flood risk management after Xynthia storm. One year after the Xynthia storm surge, which struck the Vendée and the Charente-Maritime counties of the French Atlantic Coast in the night of 27/28 February 2010, French authorities implemented a national plan for mitigation and management of the flash submersions (MEDDTL 2011). In this paper authors analyse partial results of this plan after almost three years of its effectiveness in the perspective of Xynthia catastrophic event, but also taking into account other dramatic coastal submersions, which occured during winter 2014 in the same region.
\end{abstract}

Key words: Xynthia, Flood Directive, flood risk management plan

\section{INTRODUCTION}

It is worth noting that in France approximately in 13,300 communities 17 million of people live in the areas exposed to flood risk out of which 6.1 million are settled in coastal zones. During summer period the latter figure is doubled with an important number of tourists.

\section{XYNTHIA STORM AND ITS CONSEQUENCES}

The region of French Atlantic coast, and in particular Charente-Maritime and Vendée counties, were severely touched by the storm surge Xynthia in 27-28 February 2010. Locations developed behind dikes, considered to be exposed to coastal submersion, were hit on 28 February 2010 at 2 a.m. by a storm Xynthia reaching the force of a Beaufort 10 scale ( 89 to $102 \mathrm{~km} / \mathrm{h}$ or $24.5 \mathrm{~m} / \mathrm{s}$ to $28.4 \mathrm{~m} / \mathrm{s}$ ) combined with a high tide and large waves, which caused flood defences to fail along the coast from the Gironde near Bordeaux to the Loire Estuary. Over 50,000 ha of land were flooded and 47 people died as a result of the submersion (Fig. 1) and more than 0.5 million suffered directly from the effects of the storm surge.

With more than $200 \mathrm{~km}$ of dykes damaged after being overflowed the French Departments of Vendee and Charente-Maritime suffered the most damages (Kolen et al. 2010, Departement de Charente-Maritime 2010). The total estimated damages caused by Xynthia exceed $€ 2.5$ billion (Lalande 2012), important part of it was also caused by wind gusts reaching approximately $160 \mathrm{~km} / \mathrm{h}$ at counties of Île de Ré and Deux-Sèvres. During the event around 10,000 people were forced to evacuate their homes situated in the inundated areas along the Atlantic coast. The French government declared a state of "Catastrophe Naturelle" ("Natural Disaster") in 


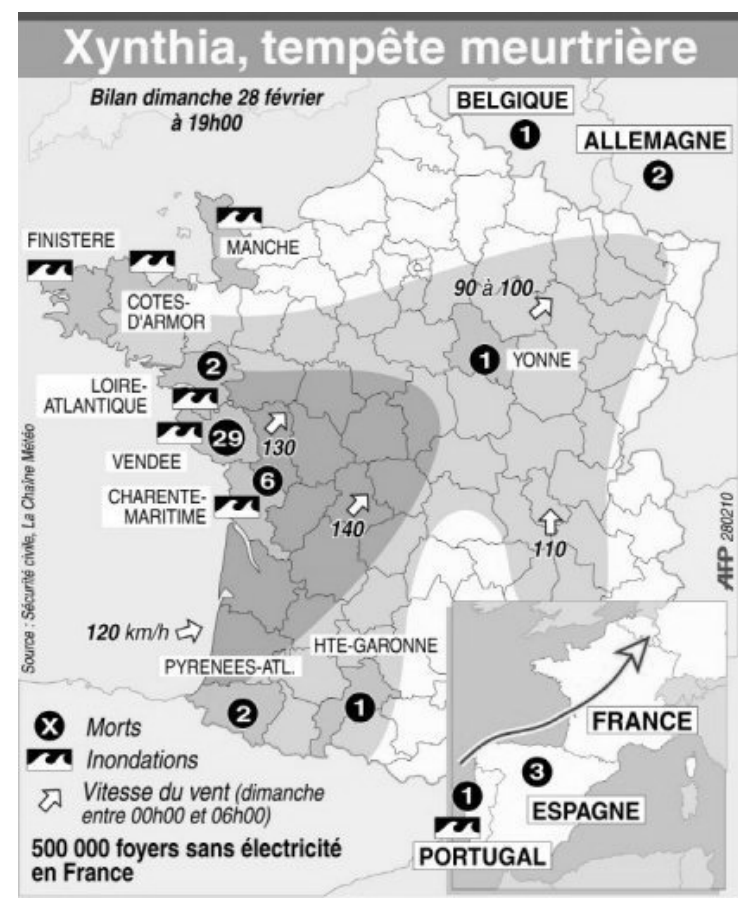

FIGURE 1. Map of Xynthia casualities (source: http://www.ladepeche.fr/article/2010/02/28/787284tempete-xynthia-fait-47-morts-selon-dernier-bilan-provisoire.html)

four Departments (Charente-Maritime, Deux-Sèvres, Vendée, and Vienne), what had an important legal consequences allowing victims to claim the compensations for the individual household and enterprise domages from the insurrance companies. It was reported that more than 9,000 French fire fighters and emergency workers backed up by helicopters were deployed on 1 March 2010 to reach residents stranded on rooftops, mostly in Vendée and Charente-Maritime (MEDDM 2010). Some of them were rescued after 4 days. Hundreds of families in coastal regions spent the night of 27/28 February 2010 and the following nights in shelters that were set up in schools and public buildings.

In the community Faute-sur-Mer (Vendée), 29 victims, for many retirees, but also some of their grandchildren came to spend a few days holiday, had been trapped in the night in their homes as electric shutters of their houses have been rendered inoperative by the water. In some houses, the water level rose to a depth of $2.5 \mathrm{~m}$ within half an hour following the failure of dikes. Some people woke up to find their beds floating $1.5 \mathrm{~m}$ above the floor (Kolen et al. 2010). In La Rochelle the sea water level reached $4.51 \mathrm{~m}$ with the setup of $1.53 \mathrm{~m}$ and Feillet et al. (2012) show that events comparable to Xynthia are rare (only ten cases observed during 27 years) or even exceptional in some stations, like at La Rochelle. Return period of storm tides vary according to the sites, from 177 years at La Rochelle for a storm of $140 \mathrm{~km} / \mathrm{h}$ (supposing superposition with 
a high tide), to only 5 years at Belle-île. Based on the analysis of historical records the return period of the Xynthia flood was estimated at more than 100 years (Anziani 2010). More precise, spatially varying flood frequence analysis was not possible due to a small sample size of extreme events.

It was therefore interesting to note the debate, which started in the media immediately after the catastrophe on the dimension of the disaster driven by a remarkable, but not extreme flood event. The disaster RETEX reports published by the French Senate (Anziani 2010) and interministerial commission (Bersani 2011) insists on the gaps in the coastal flood risk awareness and inefficiency of the alert. In fact, studies of vulnerability in the coastal regions were limited to public buildings, services and infrastructure, while there is an urgent need to assess the vulnerability of individual

a

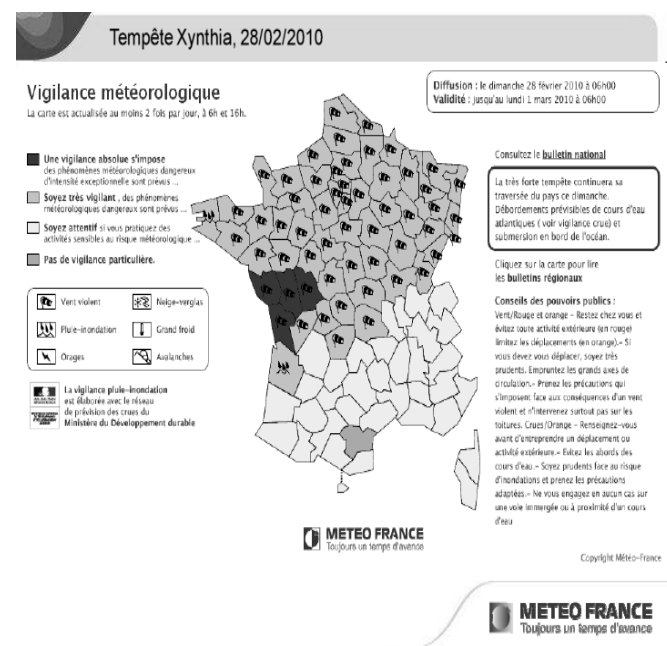

households, in particular these constructed in the flood prone areas behind dikes.

National meteorological service Méteó-France evaluates the strength of a specific weather (rainfall, wind, snow, storm, temperature etc.) and classifies each county in a four colours phenomenon alert scale from green, related to a situation requirering no particular vigilance, through yellow, orange indicating that the forecasted weather is dangerous and require population attention, with red colour used for the extreme meteorological event for which a particular precaution is necessary. Just before Xynthia hit the French Atlantic coast arround 4 p.m. on the 27 February 2010, the Charente-Maritime and neighbouring counties, were classified by Méteó-France in a red alert zone for high wind speeds following an extreme monitoring (Fig. 2).

If the general profile of the storm and its consequences at sea were well antici-

b

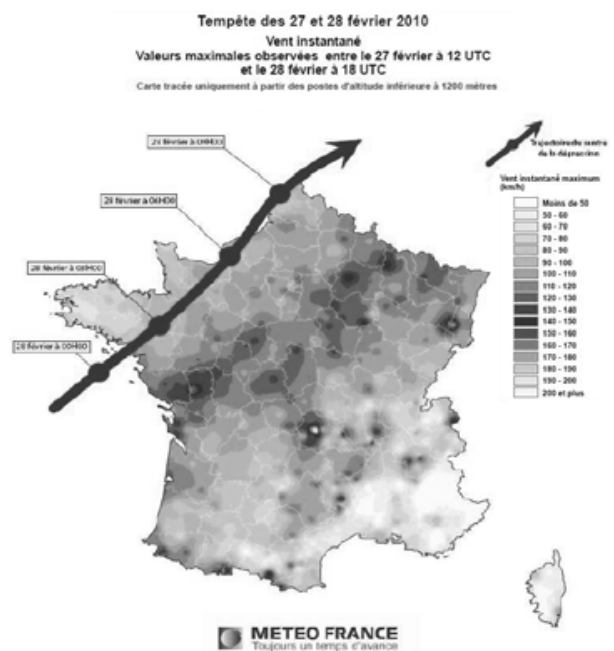

FIGURE 2. (a) Red alert from Méteó-France just before the arrival of Xynthia, (b) trajectory and observed wind speed during Xynthia (source: http://www.meteofrance.fr/climat-passe-et-futur/bilansclimatiques/bilan-2010/la-tempete-xynthia-des-2728-fevrier-2010) 
pated, this is not the case for its implications on the continent. As clearly indicate the Senate report (Anziani 2010), two organisations SHOM and Méteó-France consider in their after Xynthia RETEX analysis, the hydrodynamic forecast is not followed by an impact simulation allowing reproduction of the behavior of waves and storm surges on the coastal defense structures. Available tools allow storm surge hazard prediction well at the open sea and report potentially dangerous phenomena at a larger spatial scale, but they cannot simulate expected consequences in terms of extension of the flooded coastal areas, which are result from specific local vulnerabilities.

Sea defences in France are currently owned by an eclectic range of communities, property owners and individuals, most of whom do not have the necessary financial means for their maintenance (Lumbroso and Vinet 2011). Approximately $3,000 \mathrm{~km}$ of defences are classed as "orphelines" (orphans) by the French Government because their ownership is not known (MEDDTL 2011). In addition, in the recent past the French state has tended to withdraw funding for coastal flood defences. As a consequence, in some parts of Vendée maintenance had been left to local authorities who had to maintain $21 \mathrm{~km}$ of coastal defences with an annual budget of only $€ 70,000$ (MEDDM 2010).

Garnier and Surville (2010) relate the example of the sea surge that hit Noirmoutier Island on the coast of Vendée on the night of 13/14 March 1937. The situation was similar to Xynthia with strong winds, a spring tide and the surge occurring in the middle of the night. However, no deaths at coastal habitations were re- ported. Authors explain the absence of deaths in the 1937 surge by the fact that local awareness of the risk was high at that time and that in some areas a warning was given by an alarm bell that led to the population being prepared for the flood. The main reason for the difference in death tolls between 1937 and 2010 was combination of increasing coastal urbanization behind often weak flood defenses coupled with a decrease in the levels of flood risk awareness as a result of people moving from inland areas to the coast over the past 30 years.

Another reason of the number of fatalities is related to the land use management and developement. In fact, during last 30 years in many areas construction permits were delivered by mayors in "black zones" (named after Xynthia disaster less dramatically "solidarity zones"), with very high risk of flooding (Fig. 3).

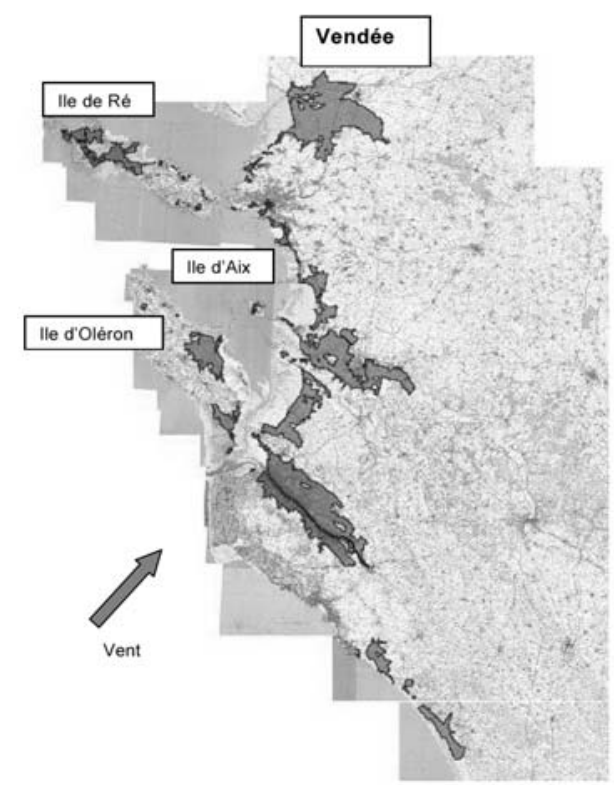

FIGURE 3. Inundated zones after Xynthia (source: Departement de Charente-Maritime, DDTM 17) 
As a result of the increasing urbanisation of the coast, the number of dwellings in the area flooded in 2010 in $\mathrm{La}$ Faute-sur-Mer increased from 508 in 1980 to 1,227 in 2010. Between 1990 and 2000, 266 out of 409 new dwellings constructed in La Faute-sur-Mer were built in flood prone areas (Roux-Goeken 2010, Lumbroso and Vinet 2011).

The governmental report prepared by MEDDTL in 2010 recommended only in Vendée demolition of 761 houses situated in such zones (Fig. 4), for which no efficient protection against coastal submersions exist. Just after the catastrophe authorities estimated the number of settlements to be demolished at 1,400 with a plan for expropriation and acquisition of land and 700 houses for approximately $€ 150$ million by the state, what created a wave of contestation by the riparians who adhered the associations defending their rights (http://www.fenvac.com, http://www.asso-avif.com) and hired experts, who contest the administrative decisions based on governmental reports.
One of the reasons of this conflict is a psychologically explained tentative of remaining in the touristic attractive area by many retired households, who put all their savings in purchased houses.

As well as their tragic human cost, Xynthia event resulted in considerable financial costs to authorities. Total public expenditure (by central government, local authorities and European funds) amounted to $€ 467$ million for Xynthia. Insurance payouts came to $€ 690$ million with approximately $50 \%$ of which was covered by the "natural disaster" government guarantee scheme. Public expenditure is funded by taxes paid by all taxpayers, while the cost of insurance claims is funded by insurance premiums and the natural disaster contribution paid by virtually everyone in the country (see section about French insurance system in this paper).

In each aspect of the crisis management (early warning, preventive measures with respect to the urban planning, protection of built-up areas and compen-

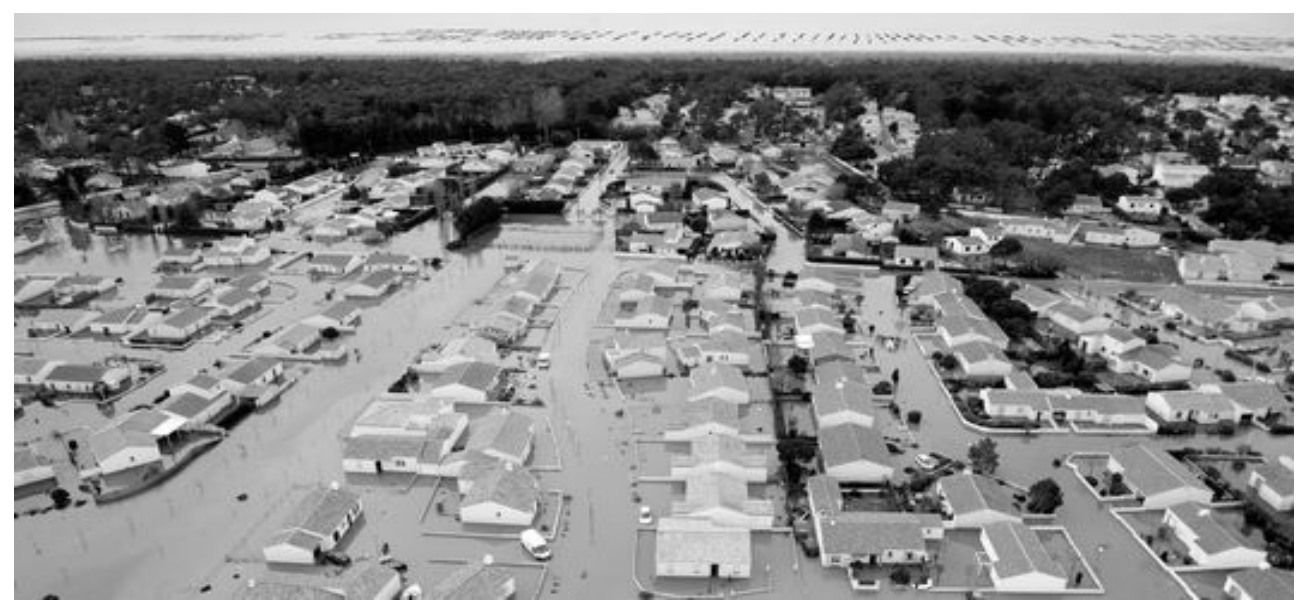

FIGURE 4. Aerial view of Port-des-Barques in Vendée county on 3 March 2010 (source: http://www. lemonde.fr/societe/article/2011/02/09/xynthia-les-maisons-des-zones-noires-ne-peuvent-etre-securisees_1477717_3224.html) 
sation system for victims) the main recommendations of the French Audit Court (Cour des Comptes 2012) were clearly oriented towards central authorities:

- bring overall consistency to steps taken by towns in relation to early warning procedures, in coordination with the future information and early warning system (SAIP);

- ensure that the forecasting of marine flooding is formally coordinated;

- immediately update risk protection plans (SDACR) and emergency response plans (ORSEC) in the most high-risk counties;

- put in place a plan related to the use of national air assets for rescue operations.

However, the most important recommendations concern preventive phase with priorities on coastal flood risk awareness:

- lay down a national flood risk strategy as required by the law (Loi no 2010$-788 \mathrm{du} 12$ juillet 2010) called Grenelle II Act (which transposes EU Flood Directive in France) and implement the EFD within the stipulated timescales;

- ensure, in implementing the European directive, that the need to make changes to existing instruments does not delay the urgent implementation of mechanisms agreed upon following the 2010 disasters;

- ensure that flood risk maps are fully distributed and relaunch the "information for buyers and tenants" scheme;

- ensure that priority risk prevention plans are implemented within the stipulated timescales;

- ensure that towns have up-to-date urban planning documents, if necessary by passing legislation to require them to do so;

- support the prefectoral administration in carrying out effective verifications of legality on urban planning decisions made by local authorities;

- introduce national management, including targets and regular feedback from Préfets, for the most sensitive procedures, such as the drawing up and distribution of risk maps, the implementation of prevention plans and the updating of the "information for buyers and tenants" scheme.

\section{XYNTHIA LESSONS \\ AND FRENCH FLOOD RISK MANAGEMENT}

\section{Xynthia and the Flood Directive implementation}

Accordingly to the Flood Directive (EU 2007), French authorities started its implementation according to the Directive's time schedule long before Xynthia event. However, Xynthia and another dramatic flash flood event in Draguignan in June 2010 with 25 casualities (Martin 2010) provided opportunity to revise and improve the national strategy and policy related to risk management.

In fact, in France since these events the time schedule for the implementation of the Flood Directive is composed of the following steps outlined on the Figure 5:

- Preliminary Evaluation of Inundation Risks (EPRI) - completed at the end of 2011;

- Definition of EPRI at the national scale and definition of criteria for 


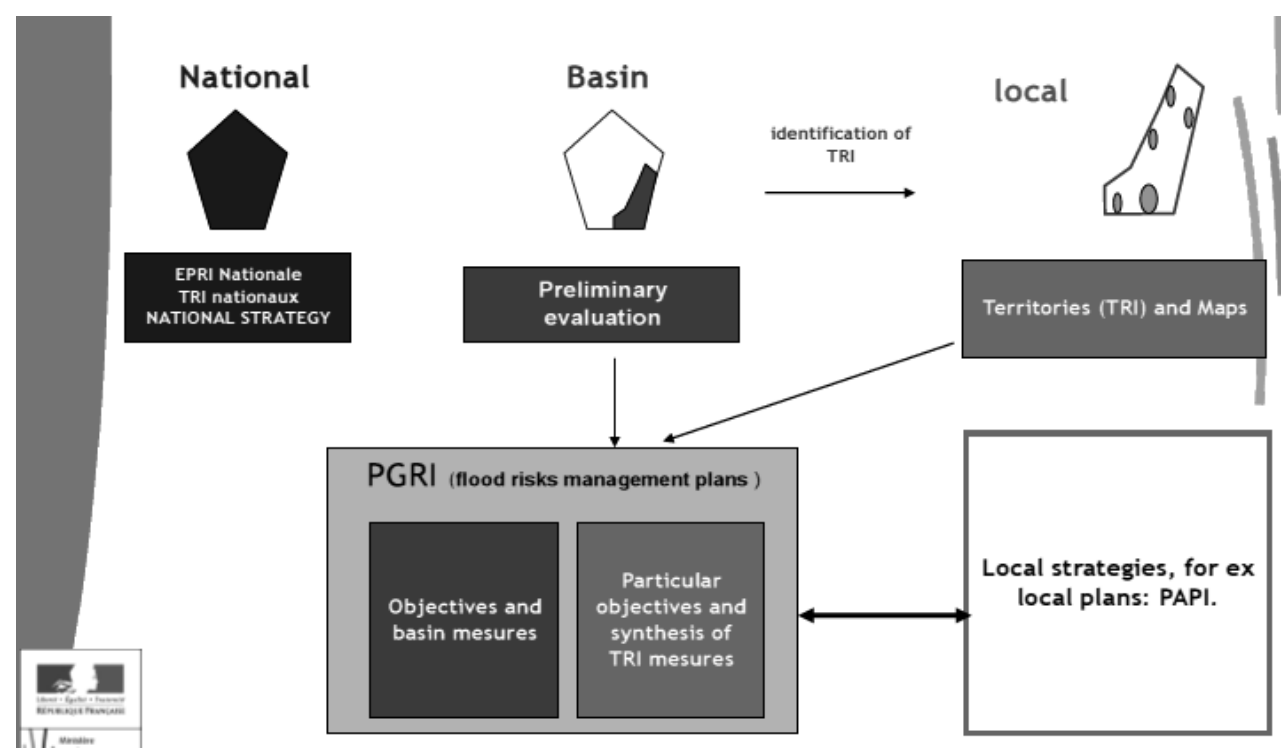

FIGURE 5. Three levels of the implementation of the Flood Directive in France (source: Lalonde 2012)

identification of the Territories of Important Risks (TRI) - completed in September 2012;

- Elaboration of the national strategy of flood risk management - draft proposal completed on end of June 2013;

- Wide public consultation of the proposal - completed in October 2013;

- Elaboration of flood risk maps for TRIs - 22 December 2013 and definition of local strategies for TRIs and their approval by Préfets - September 2014;

- Approval of the Flood Management Plans (PGRI) - 22 December 2015.

With respect to the holistic approach to Directive's implementation it appeared necessary to create in France an observatory of the evolution of the coastline and identify for each maritime facade zones exposed to significant erosion in order to prioritize appropriate actions by the public authorities.
It is also recommended on the whole French coast to strengthen the consideration of the coastal erosion in the documents of soil occupation and urban planning as well as in the flood prevention plans and in the authorizations of activity of the maritime public domain.

Under Flood Prevention Action Plans it is envisaged launching a call for projects, in the benefit of the local authorities for experimenting the solutions of a strategique withrawal and relocation of the properties and activities.

\section{Fast submersions plan (PSR)}

After an intensive and concertated work with all stakeholders in February 2011 the French Government published the document "Plan submersions rapides: Submersions marines, crues soudaines et ruptures de digues" (MEDDTL 2011). This plan details the policy response brought to the catastrophic events of 2010 and settles four priority areas as follows: 
- Control of urban developments in areas at risk of flooding;

- Improvements in coastal forecasting and warning;

- Strengthening of flood defences;

- Developing a "culture of risk awareness".

In terms of the control of urban development in flood hazard zones, the Plan envisages there will be a concerted effort to complete "Plans de Prévention des Risques Littoraux" (PPRL), i.e. coastal flood risks plans. The objective consists in setting by the end of 2015 for 242 new coastal communities a flood risk prevention plan (PPRI) and that the existing plans of a further 68 communes will also be revised. The government will introduce a law meaning that the construction of new coastal flood defences to allow new areas adjacent to the coast to be developed will be prohibited. Since the end of 2011, the French authorities have a technical reference document (EPRI) in place to assist professionals in providing flood risk management solutions.

When Xynthia occurred, although an effective fluvial flood warning and forecasting system existed this was not the case for the French coastal flood warning. The monitoring stations do not currently provide an effective way of forecasting tidal surges. There were only 17 tidal gauges on the French coast that could provide real time sea level information. A programme of upgrading tidal gauges began in 2009 as part of a project related to providing tsunami warnings (Anziani 2010).

As the result of PSR a programme to improve the real time monitoring of coastal surges and warnings for the areas with the highest risk along the French coast was initiated and the Vigilance Vague de Submersion (Coastal Submersion Vigilance) services is operational since October 2011. For each coastal county Météo-France provides a colour-coded warning (similar to that used for weather phenomena) based on the forecasted sea level and wave heights.

In 2010 French coastal defences were generally considered in a "poor" state of repair (Dupray et al. 2010). From the legal point of view Xynthia's experience brought back the problem of maintaince of protection civil works. A French act of law passed in 1807 , related to the draining of the marshlands, places the responsibility for the operation and maintenance of flood defence dikes on their owners. In France the state is responsible for checking that the owner is fulfilling their duties. More recent laws also state that the owners of dikes need to ascertain the risk that they pose to people and infrastructure (MEDDM 2010). Although the legal framework was in place to manage the defences, in reality the practice was very different owing to complex ownership structures involving a range of stakeholders (e.g. the state, local authorities, private individuals). In Charente-Maritime, only $35 \%$ of flood defence owners could be identified. In general for areas hit by Xynthia, the inventory of flood defence assets was poor. It is also important to note that other infrastructure such as road or railway embankments, which in some cases act as flood defences, have no clear legal status.

Since the flooding took place, some $€ 43$ million has been spent in the Counties of Charente-Maritime and Vendée on repairing the damage to flood defences caused by Xynthia. In February 2011 
the French Government made a commitment to make available $€ 500$ million to reinforce $1,200 \mathrm{~km}$ of flood defences between 2011 and 2016.

A list of flood defences where the risk of failure is greatest was prioritised at the end of 2011. The safety of hydraulic structures (i.e. dams and flood defences) is now the responsibility of Direction Régionale de l'Environnement, de l'Aménagement et du Logement DREAL (Regional Directorate of Environment Planning and Housing). In 2012 the central government investigated the possibility of introducing a legal mechanism via which local taxes collected at an appropriate scale can be raised to finance the maintenance of flood defences.

It was recognised by the government that there is a need to improve people's awareness of floods, especially on the coast. It was evident that many senior civil servants and communities in the Departments affected did not fully understand the nature of the flood risk. This is illustrated by an interview with Beatrice Lagarde, a high ranking official in Vendée who, immediately after the flood, spoke of the impossibility of evacuating 400,000 people (approximately two-thirds of the population of Vendée) during a storm, when actually the evacuation of a few thousand people would have saved about 30 lives (Kolen et al. 2010). In France local emergency plans, known as Plan Communal de Sauvegarde (PCS) aim to prepare communities to cope with emergencies. From 2011 onwards, it is a requirement to prepare a PCS when Plans de Prévention des Risques Littoraux - Coastal flood risk plans (PPRL) are produced. The PPRLs will have to take into account increases in sea level as a result of climate change.

The Fast Submersions Plan is now fully operational, with concrete advances on each of its priority axes. The Préfets of concerned counties have identified communities and locations for which PPRLs must be established as a priority, before the end of 2014. Generally in each region concerned by Xynthia disaster the Fast Submersions Plan applies with a priority for PPRL to be established. These plans will benefit from the detailed topography data being acquired under an agreement between the MEDDTL and the National Institute of geographic and forest information (IGN).

With respect to forecasting, vigilance and alert, since October 2011 Météo-France is providing the new service of vigilance of storm surges (in partnership with the Hydrographic Service and Oceanography Marine (SHOM), and in connection with the Ministry of Sustainable Development and the Ministry of the Interior. This vigilance has already been activated several times since its launch (in the Mediterranean in November 2011 and the Atlantic and the English Channel during the Joachim storm in December 2011, Ulla and Andrea storms in February 2014).

Reinforcement of the flood defense works and repairs have been implemented very quickly after the storm. Two levels of intervention on damaged civil works have succeeded and affected in 2010 about 190 locations (120 in Charente-Maritime and 70 in Vendée). In the Charente-Maritime county after completion of the first emergency in March 2010, 88 operations of reinforcement were performed related to all types 
of defense structures for the amount of civil works $€ 18$ million out of which $€ 9.4$ million were funded by the government. In Vendée, 56 locations of dike reparations and reinforcement of eroded dunes were launched in the county, for an amount of civil works of $€ 13.9$ million out of which $€ 6.1$ million were funded by the State.

In 2011, numerous studies have been undertaken by local authorities to establish initial estimates leading to implementation of long term program of dikes reinforcement for the next 10 years.

Finally, as regards the culture and memory of flood risk, the PRS allowed for quick installation of benchmarks limit for marine submersion in order to preserve the memory of this dramatic event.

\section{Flood Prevention Action Plans (PAPIs)}

Since 2002, before implementation of the Flood Directive, the government introduced a contractual tool between state and local self-governments for funding the Flood Prevention Action Plans (PAPIs). In consists in a national wide call for proposals having an objective to support either reinforcement civil works for flood protection or global action plans (integrating urban flood protection plans, construction of structural protection, reducing vulnerability of buildings, warning and preparedness to crisis management, preventive information...). However, the efficiency of PAPI was seriously criticised after Xynthia. In fact, Xynthia event allowed identifying serious gaps in the flood risk management in France:
- partial management of pluvial and coastal flooding, often fragmented and scattered between many stakeholders;

- insufficient involvement of collectivities, in particular in defining of protection measures, which may be expensive and not always sustainable or adequate.

Important proposals were accredited by the joint commission, which has retained 16 projects, representing a cost total of about $€ 265$ million with state assistance through the Prevention Fund of Major Natural Risks (FPRNM) more than $€ 91$ million, as part of envelope of $€ 500$ million 2011-2016 provided within the FPRNM PSR. Among 16 projects selected and labeled, 3 PAPIs and 1 PSR (dikes) concern Charente-Maritime and Vendée, mostly affected by Xynthia storm.

This work is conducted in broad partnership, mobilizing:

- Préfets and all state decentralized services, public institutions in charge of basin management;

- local stakeholders, particularly local communities, which are involved in both instances governess as well in identification of emergent projects and definitions of local strategies to be deployed under Flood Directive;

- a broad partnership around the National Observatory of Natural Hazards (Observatoire National des Risques Naturels - ONRN, www.onrn. fr), that will allow better sharing of data on the risks (hazards, vulnerabilities, stakes) and will provide support tools for decision makers. This will involve state and in particular Central Fund of Reinsurance, insurance companies, and local self-governments. 


\section{Role of French insurance system in the preparedness phase}

The French system of compensation of the victims of natural disasters, which dates in 1982, is based on the principle of the national solidarity and implemented through a compulsory additional contribution of every person signing an insurance multi-risk contract for a house or an apartment. This earmarked contribution of all insured allows the extension of the guarantee covering the effects of natural disasters for which the state of "natural catastrophe" (called CatNat) was notified by governmental order. The order defines the zones and periods in which the disaster is "recognized" as well as the nature of the inflicted damage. The justification of this system of officially "recognized" natural catastrophes is based on the exceptional intensity of such phenomena. The CatNat represents one of the important criteria allowing judgement of the communes' experienced vulnerability with respect to natural hazards.

The CatNat guarantee is framed by the state by four elements which escape the control of the insurer:

- the definition of the covered risks;

- the minimum threshold of damage compensation (e.g. goods for domestic use: $€ 380$ ( $€ 1,520$ for droughts), goods for professional use: $10 \%$ of damages (with à minimum of $€ 1,140$ ); exploitation losses: 3 working days (minimum $€ 1,140$ );

- the pricing of the surcharge;

- the declaration of the state of natural disaster.

At present the rates of the prime are the following:
- for all goods except vehicles with an engine: $12 \%$ of the premium for the contract without catastrophe guarantee;

- for terestrial vehicles with an engine: $6 \%$ of the premium related to theft and fire.

The premium rate is independent of the hazard type and is not connected to implemented preventive measures, what is consider as its weakness.

So far, the French system of compensations of damages due to natural catastrophes, guaranteed by the state and facilitated by insurance pooling, allow balancing of good and bad years in terms of damage from natural hazard. Yet, climate studies, such as conducted by the FFSA in 2009, question the long-term robustness of the system. Indeed, while between 1988 and 2007, the cost of natural events compensated by French insurers amounted to $€ 34$ billion, for the period 2009-2030 the estimates go up to $€ 60$ billion. However, $65 \sim 80 \%$ of this rise is owing to rising wealth levels, leaving a third or less to effects of climate change and other factors. Anticipatory land use planning, risk disclosure and insurances that promote vulnerability reduction may reduce the rise in damage cost appreciably. Conversely, absence of these measures may reinforce the rising damage cost trend. Insurance companies are keen to mobilize all stakeholders around the theme of prevention.

The incentivizing features of CatNat could be enhanced, which may help to maintain reasonably high compensation levels and moderate premium levels. There is also a need to organise a joint discussion process on increasing insurance cover for properties owned by local authorities. 
THE NEVERENDING STORY OR COASTAL SUBMERSION DURING WINTER 2013/2014

According to Météo-France (Météo-France 2014), the winter 2013-2014 third hottest since the beginning of XX century, was marked by a series of storms and disturbances coming from the Atlantic Ocean, the result of a strengthened Azores anticyclone and a depression over Iceland more hollow than normal. Strong winds associated with these storms have affected almost the entire country and particularly the coasts of the Atlantic and the Channel. However, none of these storms is considered at French locations as an exceptional event:

- storm Xaver of 5 December 2013 (aka Berit, Sven, Ksawery) was the most violent since decades in northern Europe. But it missed France and only the region Nord-Pas-de-Calais has suffered strong gales with gusts reaching $80-90 \mathrm{~km} / \mathrm{h}$ in general, occasionally $100 \mathrm{~km} / \mathrm{h}$ on the coast;

- Storm Dirk from 23 to 25 December 2013 has spread to almost all of France on 24th before leaving the country by the eastern flank on December 25 th. Wind gusts have reached 90 $-120 \mathrm{~km} / \mathrm{h}$ in inland and up to $140 \mathrm{~km} / \mathrm{h}$ on the north-west coast as well as in the mountainous regions;

- Storm Ulla of 14/15 February 2014 was circulating off Brittany, with exceptional activity on the British Isles. The storm, which affected the northwest of France, was the most violent of this winter at the tip of Brittany with winds exceeding $150 \mathrm{~km} / \mathrm{h}$ on the coast. In inland, winds SSW gusts reached $90-110 \mathrm{~km} / \mathrm{h}$.
Moreover, between passages Dirk and Ulla, several other storms have succeeded in France during the first half of February 2014, including Petra on 4-5 February, Qumaira on 6-7th, Ruth on 8th, Tini on 12-13th, Andréa on 28th. These storms, less violent than Dirk and Ulla in France, on the other hand have affected more severely Great Britain.

As the consequence of the weather vagaries the cumulative rainfall during the winter period was between 350 and $1,000 \mathrm{~mm}, 1.5-2$ times locally of the normal for the season (Fig. 6). Such exceptional rains, combined with coastal flooding during high tides in January and February 2014 caused extensive flooding in Brittany and Normandy. Several locations (Morlaix, Quimperlé, Quimper) stayed submerged for weeks.

Winter storms have been costly to the insured. Insurance companies will have to de-burse approximately $€ 500$ million for all weather events that occurred between late December 2013 and March 2014 (Assurer 2014). Over the last eight months of 2013 French insurers indicate that the cost of natural disasters weigh for $€ 2$ billion, exceeding the annual average of $€ 1.5$ billion per year recorded over the past twenty years. Globally, the 2013 was a remarkable year in natural disasters and it is not unrelated to global warming, according to the World Meteorological Organization (WMO 2013). In France, in 2009, the FFSA (French Federation of Insurance) conducted a study on climate change finding a potential doubling of the cost of compensation related to natural hazards in 2030 (Assurer 2014). 

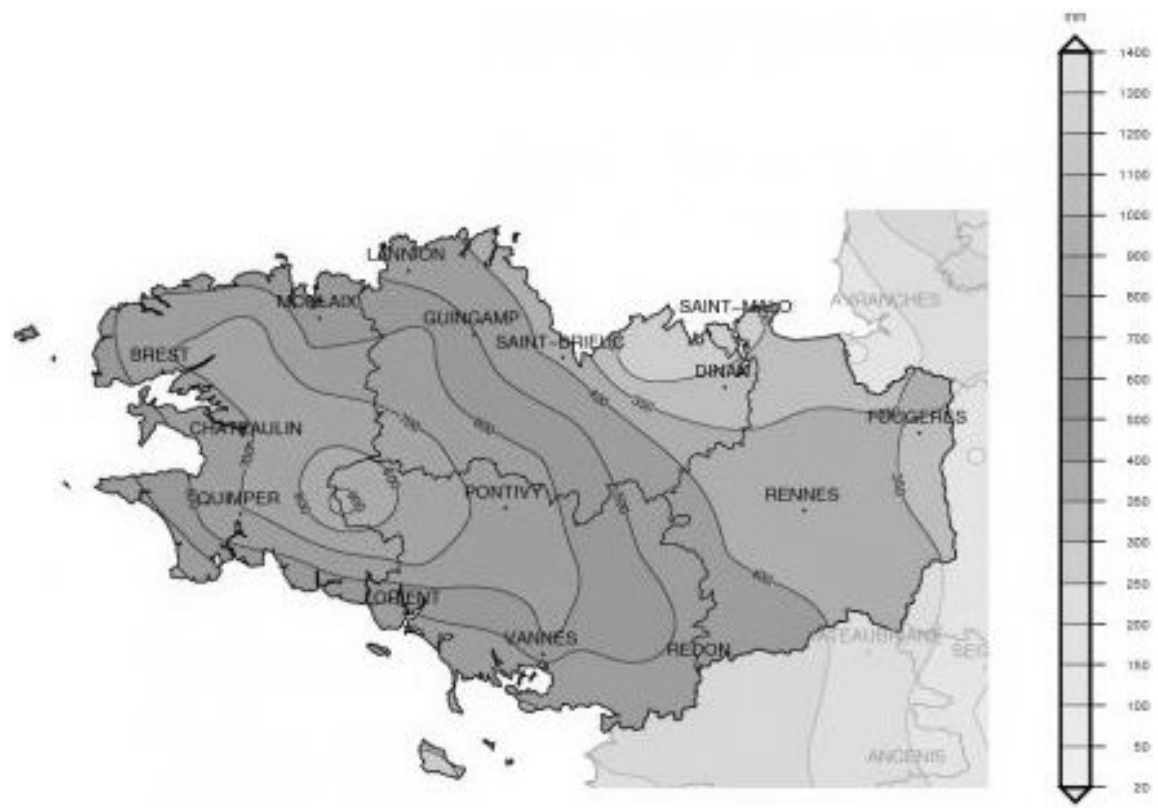

FIGURE 6. Cumulated rainfall (in mm) during winter 2013/2014 in Brittany (Météo-France, source: http://bretagne.france3.fr/2014/03/03/bretagne-1-hiver-2014-est-le-plus-pluvieux-depuis-1950425879.html)

\section{CONCLUSIONS}

The Fast Submersion Plan (PSR) introduced in France one year after Xynthia event responded to three urgent needs:

- to impulse actions to reduce the risks for human life in areas in danger of sea submersion, flash floods or levees failures;

- to allow to anticipate the national strategy of flood protection;

- to select operational projects to secure the population in low areas and to identify an owner with the technical and financial skills for each dike.

More than 70 operational actions were already implemented and they are accompanied by Flood Prevention Action Plans (PAPIs). However the challenging problem to be solved is that of population already leaving in flood prone areas, for which adequate no structural solutions for mitigation of flood risk must be found. In Vendée, after Xynthia, some of inhabitants were authorised to stay in their houses, classified in the preliminary analysis by the authorities as to be destructed, under condition of adaptation of the buildings to flooding. The works, to be carried by the owners include: construction of shelters at a minimal heights of $5 \mathrm{~m}$ (by adding an additional store), direct access through the roof opening for rescue from helicopters and if a home is equipped with electric shutters it is advisable under safety, to have at least one that is manual or disengaged, to allow opening without electricity and thus facilitate the evacuation. Such preventive measures improving safety allowed classification of the houses from "red" to "yellow" zone. 
In addition, recent dramatic events will impact the insurance policy. So far, the French system of compensations of damages due to natural catastrophes, guaranteed by the state and specific to insurance pooling allow balancing the good and bad years in terms of natural events. But climate studies such as that conducted by the FFSA in 2009 challenge question current technical balances. Indeed, while between 1988 and 2007, the cost natural events compensated by French insurers accounted for $€ 34$ billion, an estimated cost for the period between 2009 and 2030 could reach $€ 60$ billion. The proliferation of weather conditions observed over the entire planet can only support this thesis. This is why insurers want to mobilize all stakeholders around the theme of prevention. Inevitably the equilibrium would be reached by either reduction of the level of compensations or increase of the primes, which are today, based on a solidarity and mutualisation principles of a $12 \%$ CatNat tax for each household insurance policy.

But the real long-term lesson drawn from Xynthia and other storms in France is a need for a complete revision of the coastal settlements, which during last two centuries had little in common with a sustainable development.

Finally, Xynthia and its repercussions are revelations of the weakness of the awareness of the risks on vulnerable coastal territories and the depth of the collective lack of responsibility (Chauveau et al. 2011). The previous generations were less deprived from this point of view therefore the effort of pedagogy and dialogue to be deployed in this domain is only bigger.

\section{REFERENCES}

Assurer FFSA 2014: Face aux catastrophes naturelles, la prévention est la meilleure réponse. La Lettre de la Féderation Française des Sociétés d'Assurances, No 211, March 24th, 2014 (http://www.ffsa.fr/ sites/upload/docs/application/pdf/2014-03/assurer211.pdf).

ANZIANI A. 2010: Rapport d'information fait au nom de la mission commune d'information sur les conséquences de la tempête Xynthia, rapport d'étape 10/6/2010, No 554. Sénat, session ordinaire de 2009-2010 (http://www.senat. fr/rap/r09-554/r09-5541.pdf).

BERSANI C., GERARD F., GONDRIAN O., HELIAS A., MARTIN X., PUECH P., DUMAS P., ROUZEAU M., FLEURY B., GREF M., BOUGERE R., TREPOS Y. 2011: Tempete Xynthia retour d'experience, evaluation et propositions d'action tome I: rapport. MEEDTLM, May 2010, Ref. 104000293.

CHAUVEAU E., CHADENAS C., COMENTALE B., POTTIER P., BLANLCEIL A., FEUILLET T., MERCIER D., POURINET L., ROLLO N., TILLIER I., TROUILLET B. 2011: Xynthia: leçons d'une catastrophe, Cybergeo: European Journal of Geography [on-line], Environnement, Nature, Paysage, document 538 , mis en ligne le 09 juin 2011, consulté le 17 août 2014 (http://cybergeo. revues.org/23763; DOI: 10.4000/cybergeo.23763).

Cour des Comptes 2012: Lessons from the 2010 floods on the Atlantic Coast (Xynthia) and the Var. Summary of the Public Thematic Report, July 2012.

Departement de Charente-Maritime 2010: Tempete Xynthia du 28 fevrier 2010. Direction des territoires et de la Mer (DDTM 17).

DUPRAY S., TOURMENT R., POHL R., SCHELFHOUT H., WILLIAMSON T., GAMST K., SHARP M. 2010: International levee handbook - Scoping re- 
port (http://cemadoc.irstea.fr/cemoa/ PUB00033808).

EU 2007: Directive 2007/60/EC of the European Parliament and the council of 23 October 2007 on the assessment and management of flood risks. Official Journal of the European Union, L 288/27.

FEUILLET T., CHAUVEAU E., POURINET L. 2012: Xynthia est-elle exceptionnelle? Réflexions sur l'évolution et les temps de retour des tempêtes, des marées de tempête, et des risques de surcotes associés sur la façade atlantique française, 222 (http://norois.revues.org/3866).

GARNIER E., SURVILLE F., BOUCARD J. 2010: La tempête Xynthia face à l'histoire - Submersions et tsunamis sur les littoraux français du Moyen Age à nos jours. Le Croît Vif, Editions charentaises.

Loi no 2010-788 du 12 juillet 2010 portant engagement national pour l'environnement.

KOLEN B., SLOMP R., van BALEN W., TERPSTRA T., BOTTEMA M., NIEUWENHUIS S. 2010: Retour d'expériences après la tempête Xynthia en France, leçons pour les Pays Bas.Les dégâts suite à l'inondation. HKV LIJN IN WATER and Rijkswaterstaat, Waterdienst.

LALANDE J.P. 2012: The influence of Xynthia on Policy and Practice.French national policy for flood risk management. Key-note lecture at FLOODRisk 2012 Conference, Rotterdam, November 2012.

LUMBROSO D.M., VINET F. 2011: A comparison of the causes, effects and aftermaths of the coastal flooding of England in 1953 and France in 2010. Nat. Hazards Earth Syst. Sci., 11, 2321-2333, doi:10.5194/nhess-11-2321-2011.

MARTIN C. 2010: Les inondations du 15 juin 2010 dans le centre Var: réflexion sur un épisode exceptionnel. Études de Géographie Physique XXXVII, 41-76.

Météo-France 2014: Bilan climatique de l'hiver 2013-2014 (http://www.meteofrance.fr/climat-passe-et-futur/bilans-cli- matiques/bilan-2014/bilan-climatiquede-1-hiver-2013-2014).

Ministère de l'Ecologie et du Développement Durable et de la Mer 2010: Directions Régionales de L'Environnement, Tempête Xynthia - Retour d'expérience, évaluation et propositions d'action. Rapport du gouvernement français, 2 Tomes.

Ministère de l'Ecologie, du Développement Durable, des Transports et du Logement 2011: Plan submersions rapides (http:// www.developpement-durable.gouv.fr/ IMG/pdf/Le_plan_submersion_rapide. pdf ).

Ministère de l'Ecologie, du Développement Durable, des Transports et du Logement 2010: Vigicrues: Information sur la vigilance crues (www.vigicrues.ecologie. gouv.fr).

News-Assurances 2014: Assurance intempéries: 500 millions d'euros pour les tempêtes hivernales (http://www.news-assurances.com/actualites/assurance-catastrophe-500-millions-deuros-les-intemperies-decembre-fevrier/016782114\#, 25 March 2014).

NUSSBAUM R. 2013: Prevention et assurance des catastrophes naturelles l'expérience française. FORMOSE-CHANGES, Conférence Publique, Barcelonette, 24 June 2013.

ROUX-GOEKEN V. 2010: Tempête Xynthia: les trois failles françaises (http://www. actu-environnement.com/ae/news/tempete-xynthia-inondation-plan-digues-urbanisation_9716.php4, 3 March 2010).

WMO 2013: $\bar{A}$ summary of current climate change findings and figures. March 2013, (http://www.wmo.int/pages/mediacentre/ factsheet/documents/Climate-ChangeInfo-Sheet-136_fr.pdf. March 2013).

Streszczenie: Co zmienito się we Francji $w$ zarzadzaniu ryzykiem powodziowym na wybrzeżach po sztormie Xynthia. W rok po sztormie Xynthia, który w nocy z 27 na 28 lutego 2010 roku w tragiczny sposób dotknął departamenty Vendée i Charente-Maritime francuskiego wybrzeża Atlantyku, władze wprowadziły krajowy plan 
ograniczania skutków szybkich powodzi (MEDDTL 2011). Dotyczy on także sposobów zarządzania zalewami morskimi. W niniejszym artykule analizowano częściowe wyniki realizacji tego planu oraz jego skuteczności w perspektywie katastrofy Xynthia oraz w świetle innych dramatycznych powodzi przybrzeżnych, które wystapiły $\mathrm{w}$ okresie zimowym 2013/2014 w Bretanii. Jedną z długoterminowych lekcji, która należy wyciagnąć z Xynthii, jest pilna potrzeba całkowitej zmiany gospodarki przestrzennej nadbrzeżnych osiedli, która od ponad dwóch wieków nie miała wiele wspólnego z zasadami zrównoważonego rozwoju. Sam żywioł i jego następstwa objawiły również słabą świadomość ryzyka powodziowego na terenach przybrzeżnych i głęboki brak odpowiedzialności zbiorowej zarówno władz samorządowych, jak i administracji.

Stowa kluczowe: Xynthia, Dyrektywa Powodziowa, plan zarządzania ryzykiem powodziowym

MS. received August 2014

\section{Author's address:}

Marc Erlich

ARTELIA Eau et Environnement

6 rue de Lorraine, 38130 Echirolles

France

e-mail: marc.erlich@arteliagroup.com 